\title{
Computer Assisted Instruction (Cai) On Students' Interest And Achievement In Physics In Imo State, Nigeria
}

\author{
Nwanne Stephen Chinwendu ${ }^{1}$, Agommuoh Patience $C^{2}$. \\ ${ }^{1,2}$ Department of Science Education, Michael Okpara University of Agriculture Umudike, Umuahia Abia State, \\ Nigeria.
}

\begin{abstract}
This study determined the effect of Computer Assisted Instruction (CAI) on students' interest and achievement in physics. Two research questions were posed and two hypotheses were formulated and tested. A quasi experimental design specifically the non-randomized control group design involving two intact classes was used. The sample of the study consist of 97 senior secondary school two (SSII) physics students from two government owned secondary schools drawn using purposive sampling techniques from 63 government schools that offer physics in Imo State. One of the two schools used was assigned to experimental group (CAI) and the other one to the control group (LM). Two instruments, the Physics Achievement Test (PAT) and the physics Interest Inventory (PII) were developed and validated. An internal consistency of PAT was computed and found to be 0.82 using Kuder -Richardson formula 20 (KR 20). Before treatment commenced, the PAT was administered as pre-test to the two groups. Means and standard deviations were used to answer the research questions. Hypotheses were tested using Analysis of Covariance (ANCOVA) at 0.05 level of significance. The result of the analysis indicated that CAI had significant effects on students' interest and achievement in physics, where students in the CAI group achieved more. Thus, it is recommended among others, that State Governments, Ministries of Education and professional associations should organize workshops, seminars and conferences to train teachers on the use of CAI techniques.
\end{abstract}

Keywords: Computer Assisted Instruction, Teaching Physics, Interest, Achievement.

\section{Introduction}

Computer Assisted Instruction (CAI) is an interactive technique whereby a computer is used to present the material and also to monitor the learning that takes place (Iqbal, 2009). It is also known as ComputerAssisted Learning (CAL), Computer Assisted Education (CAE) and Computer-Assisted Training (CAT). CAI programs motivate the students and arouse their interest in teaching and learning process (Iqbal, 2009). Different modes of computer assisted instruction exist. These include; Drill and Practice for repetitive exercise and rote skills, Instructional Games which Increase learners' motivation by adding game rules to learning activity. Tutorials which are deliver as instructional activities, quiz and feedback. Problem solving software which present problems relevant to learning objectives, provide necessary directions, hints and assistance to solve problem according to the learners' need. Simulation which present computerized model of a real or imagined system to teach how a system works. Integrated learning system which is a combination of drill and practice, tutorial, simulation and problem solving, Micro computer based laboratories which enable the experimenters to automate the process of gathering data from experiment, conduct relevant analysis and produce meaningful reports, enhance speed and ensure precision of data collection. Teachers using CAI can generally achieve the following results in more student-centered teaching: less lecturing, increased individual instruction, more time spent in coaching and advising students, increased interest in teaching and increased productivity. In Computer assisted instruction course, contents are divided into "frames" which enabled the students to master the content in a specific sequence. Most of the Computer assisted instruction packages are computerized version of teaching techniques which are applied in stimulating teaching and learning of physics. In Computer Assisted Instruction, information is presented on computer display, students are asked to respond, and their response is evaluated. If response is correct, student moves ahead, if incorrect, similar problems are presented till correct response is elicited.

For any nation to attain self-reliance, science must be an important component of the knowledge to be given to her citizens irrespective of tribe/ethnicity, creed or gender (Ezenwa, 2011). Physics is the most basic science which deals with the study of nature and natural phenomena. Understanding science begins with understanding physics. With every passing day, physics has brought to us deeper levels of understanding of nature. Everything we know about physical world and about the principles that govern its behaviour has been learned through observations of the phenomena of nature. Physics is one of the science subjects taught at the senior secondary school level of the Nigeria educational system. The study and application of physics is essential to the scientific, industrial, technological and social advancement of societies or nations. Physics education is aimed at training students to acquire proper understanding of physics principles as well as their 
applications. It is also aimed at developing in them appropriate scientific skills and attitudes as a pre-requisite for future scientific activities. To achieve these objectives, innovative teaching techniques, active participation and collaborative learning activities become imperative and these would need functioning instructional media such as the use of CAI to make physics instruction effective (Alebiosu \& Mudasiru, 2008; Ogunleye, 2000).

It is a thing of worry that large number of students do not seem to understand the basic concept in physics at secondary school level. Learning tends to be by rote and memorization and students find learning of physics difficult, boring and uninteresting which in turn affect their academic achievement negatively (Eyibe, 2010; Jegede, 2012; Salau, 2006). The quality of physics teaching and learning has also been questioned over time by parents, science educators, the general public and even the government (Adepoju, 2001; Ivowi, Okebukola, Oludotun \& Akpan, 2002; Okebukola, 2007). Physics teaching in Nigerian schools has not been encouraging because of the poor performance of students in physics relative to their counterparts in other countries. Research indicates that many students found physics to be difficult, boring and not interesting (Salau, 2006). This is also evident in a recent report by the Shelter Right Initiative (Olubusuyi, 2003) where it was stated that for eight consecutive years, between 2002 and 2009, Nigerian candidates trailed behind their counterparts from other countries in the West African region based on performance in science subjects (physics) conducted by the West African Examinations Council (WAEC).A number of factors have been identified to be responsible for these poor performances and lack of interest in physics from the various studies conducted in Nigeria. These include the lack of motivation for most teachers, poor infrastructural facilities, inadequate textual materials, attitude of students to learning, lack and inappropriate teaching method to meet the demand of the society in which we live and the yelling of the changing world ,among others (Braimoh \& Okedeyi, 2001; Folaranmi, 2002; Okebukola, 2007; Olaleye, 2002; Olanrewaju, 2004). Studies indicate that research efforts have proposed various suggestions and recommendations for improving the quality of physics teaching and learning in Nigerian classrooms (Ajewole, 2004; Busari, 2006; Igwebuike, 2006; Odubunmi, 2001). However, despite these various suggestions and recommendations for improvement, the quality of physics teaching and learning and student's achievement in senior secondary school physics continues to decline (Ikeobi, 2005; Ivowi, 2005). The current situation of physics teaching and learning in Imo State and Nigeria is a concern to all including government and the society at large. Hence the need to explore the efficacy of Computer Assisted Instruction (CAI) method in teaching and learning of physics at secondary school level in Imo State. Schiefele (2008) maintained that one's interest is enkindled or killed through participation, experience, familiarity, study and work. It is what one perceives in these engagements that shape his interest (Hidi, 2000). Meera (2000) opined that interest most often is directly tied to the content or instruction and it also directs and enhances learning. Most researchers believed that interest emerges from an individual's interaction with his or her environment.. An increase in knowledge can bring about positive effect as individuals feel more competent and skilled through task engagement. In addition, as they spend more time with the activities in CAI, they may find personal meaning and relevance in the activities, such as when a high school student discovers that an understanding of physics can help her pursue her dream of becoming a physicist, technologist or engineer. Patel and Kinnary (2008) in their study on "Effects of Computer - Based Teaching on secondary school students" also found out that the use of CAI in teaching electronics students improved their interest in the subject than the students taught electronics with traditional instructional methods. It is therefore believed that interest is an important outcome, and that it is a crucial component of success in academics, sports, or other areas of our lives (Kadhiravan,2009; Hema;2003 \& Dalwadi, 2001.

Chukwu (2007) explained that academic achievement of student is the ability of the student to study and remember facts and being able to communicate his knowledge orally or in written form even in an examination condition. Secondary education plays a crucial role in laying the foundation for the further education of students. If a good foundation is laid at the secondary school level, students can better cope with the challenges of life and profession with great ease. Factors that influence students' academic achievement at the senior secondary school might include students' attitude towards school, interest in learning, teaching method, study habit, attribution, self-efficacy, intelligence, and motivation. Thus, students' academic achievement cannot be completely accounted for by only one or two variables but a number of them. This implies that students' academic performance could be enhanced through identifying and manipulating each of such variables (Igwebuike; 2007). Based on this, the study tried to investigate the effect of computer assisted instruction (CAI) on physics student's interest and achievement in senior secondary schools in Imo state, Nigeria.

\section{Research Questions}

The following research questions were formulated to guide this study:

1. What are the mean interest scores of students taught physics with Computer Assisted Instruction (CAI) and those taught using the lecture method? 
2. What are the mean achievement scores of students taught physics with Computer Assisted Instruction (CAI) and those taught using the lecture method?

\section{Hypotheses}

The following null hypotheses were tested at 0.05 level of significance.

$\mathrm{Ho}_{1}$ : There is no statistically significant difference between the mean interest scores of students taught physics with Computer assisted instruction (CAI) and those taught using lecture teaching method as measured by PII

$\mathrm{Ho}_{2}$ : There is no statistically significant difference between the mean achievement scores of students taught physics with Computer assisted instruction (CAI) and those taught using lecture teaching methods as measured by PAT.

\section{Method}

This study adopted a quasi-experimental design using pre-test and post-test with control and experimental groups. The study was carried out in Imo State. The state comprises three education zones namely Orlu, Owerri and Okigwe. These education zones have twenty seven (27) Local Government Areas. Orlu has nine; Owerri has twelve while Okigwe has six. The population of this study comprised of 7,825 senior secondary two (SSII) physics students in all the public senior secondary schools in Imo state (SEMB Owerri). A two-stage sampling techniques was adopted. Firstly, a purposive random sampling was adopted to obtain two secondary schools in Imo State. Secondly, the two sampled equivalent and co-educational/mixed schools were randomly assigned to experimental groups and control group using simple random sampling technique. One school was assigned to experimental group with 49 physics students and was treated with Computer Assisted instruction method (CAI), the other school was assigned to control group with 48 physics students and was taught using the Lecture Method (LM). Two instruments were used for collecting data. They are; Physics Achievement Test (PAT) and Physics Interest Inventory (PII). The physics Achievement Test is a 50 item multiple choice type questions which was developed by the researcher from the six content areas used for the study. The multiple choice items were drawn using the table of specification. The second instrument used for data collection is the physics Interest Inventory (PII) which is made up of two parts; Section A which deals with the background information of the respondents and section $\mathrm{B}$ which deals with the questions with reference to students' interest in physics in public secondary schools in Imo State. This was based on 15 items on a four point modified scale type of Strongly Agree (SA), Agree (A), Disagree (DA) and Strongly Disagree (SD).The instruments were validated and a reliability coefficient of 0.82 was obtained. Data generated from the pre-test and post-test were used for the analysis. Mean and Standard deviation were used to answer the research questions while the analysis of covariance (ANCOVA) and t-test were used for testing the hypotheses at 0.05 level of significance.

\section{Results}

Table 1. Mean Interest Scores of Students taught Physics with Computer Assisted Instruction and those taught using the Lecture Method

\begin{tabular}{|l|l|l|l|}
\hline VARIABLES & $\mathrm{N}$ & MEAN & SD \\
\hline LM & 48 & 2.75 & 0.66 \\
\hline CAI & 49 & 3.11 & 0.76 \\
\hline POOLED MEAN & 97 & 2.93 & 0.71 \\
\hline
\end{tabular}

Data in Table 1 shows that the students taught with CAI have more interest in learning physics than those taught using the lecture method as indicated by the mean interest scores of $3.11(\mathrm{CAI}), 2.75(\mathrm{LM})$ with the mean gain scores of 0.36

Table 2: Mean Achievement Scores of Students taught Physics with Computer Assisted Instruction and those taught using the Lecture Method

\begin{tabular}{|l|l|l|l|l|l|l|}
\hline VARIABLES & N & MEAN & SD & Pre test mean & Post test mean & Mean Gain \\
\hline LM & 48 & 63.13 & 7.14 & 36.90 & 63.13 & 26.23 \\
\hline CAI & 49 & 75.08 & 6.03 & 36.90 & 75.08 & 38.18 \\
\hline POOLED MEAN & 97 & 69.17 & 8.90 & & & \\
\end{tabular}

Data in Table 2 shows that the students taught with CAI performed better than those taught using the lecture method as indicated by the mean achievement scores of 75.08(CAI), 63.13(CTA) with the mean gain scores of 11.95 
Table 3: t-test Analysis of the Mean Interest Scores of Students taught Physics with Computer Assisted Instruction (CAI) and those taught using Lecture Method

\begin{tabular}{|l|l|l|l|l|l|l|l|l|}
\hline Variable & $\mathrm{N}$ & Mean & $\mathrm{SD}$ & $\mathrm{DF}$ & Standard Error & $\mathrm{t}_{\text {-cal }}$ & $\mathrm{t}_{\text {-critical }}$ & $\mathrm{P}_{\text {-value }}$ \\
\hline LM & $\mathbf{4 8}$ & $\mathbf{3 . 1 1}$ & $\mathbf{1 . 7 6}$ & & & & & \\
\hline & & & & & & & & \\
\hline & & & & $\mathbf{9 5}$ & $\mathbf{0 . 1 3}$ & $\mathbf{2 . 6 7}$ & $\mathbf{1 . 9 6}$ & $\mathbf{0 . 0 0 8}$ \\
\hline & & & & & & & & \\
\hline CAI & & & & & & & & \\
\hline
\end{tabular}

The results of the above analysis showed that the calculated t-value of 2.67 with 95 degree of freedom is greater than the critical t-value of 1.96. We have enough evidence to reject the null hypothesis and state that there is a statistically significant difference between the mean interest scores of students taught physics with computer assisted instruction (CAI) and those taught using lecture method as measured by interest inventory items. This suggests that students exposed to CAI tends to have more interest in learning physics than those taught with lecture method.

Table 4: Analysis of Covariance on the Mean Achievement Scores of Students exposed to CAI and LM

\begin{tabular}{|l|l|l|l|l|l|l|}
\hline Source of variation & Sum of Squares & Df & Mean Square & F & p-value. & Partial Squared \\
\hline Corrected Model & $4317.548^{a}$ & 2 & 2158.774 & 61.645 & .000 & .567 \\
\hline Intercept & 6942.716 & 1 & 6942.716 & 198.254 & .000 & .678 \\
\hline Teaching Method & 3528.143 & 1 & 3528.143 & 100.749 & .000 & .517 \\
\hline Post test & 851.111 & 1 & 851.111 & 24.304 & .000 & .205 \\
\hline Error & 3291.813 & 94 & 35.019 & & & \\
\hline Total & 471637.000 & 97 & & & & \\
\hline Corrected Total & 7609.361 & 96 & & & & \\
\hline
\end{tabular}

a. $\mathrm{R}$ Squared $=.567$ (Adjusted R Squared $=.558$ )

Data in Table 4 shows that the F-ratio of 100.749 with $(1,94)$ degree of freedom. However, since the alpha at 0.05 is greater than the p-value at $0.000 .(\mathrm{p}<0.05)$ we have enough evidence to reject the null hypothesis and state that there was a significant difference between the mean achievement scores of students taught physics with computer assisted instruction (CAI) and those taught using conventional teaching method as measured by PAT. Moreover, that there is a statistically significant difference between adjusted mean of the two Teaching Method used (Adjusted R Squared $=.558$ ). This suggests that students treated with CAI performed better than those in lecture group.

\section{Discussion}

Finding from table 1 revealed that students taught physics with CAI had a higher mean interest score than those students taught using the lecture teaching method in the physics interest inventory. In the same vein, the results of the above analysis showed that the $\mathrm{t}$-cal is 2.67 , t-critical is 1.96 with (95) degree of freedom. However, since the $\mathrm{t}$-cal is greater than the $\mathrm{t}$-critical a $(\mathrm{t}$-cal $<\mathrm{t}$-crit) we reject the null hypothesis and state that there is a statistically significant difference between the mean interest scores of students taught physics with computer assisted instruction (CAI) and those taught using lecture teaching method as measured by physics interest inventory items. This suggests that students exposed with CAI tend to have more interest in learning physics than those taught with lecture teaching method. The implication of this finding therefore is that CAI is more effective than lecture teaching methods in enhancing students' interest in physics. This finding is similar to the finding of Singh (2005) who found that there was a significant difference in interest in mathematics of experimental group taught with CAI and control group taught with conventional teaching methods in favour of the experimental group. The difference in the interest of students in physics is similar with the studies carried out in other fields of learning on students' interest by Meera (2000). Kadhiravan (2009) in his study found that the adoption of any treatment as an instructional framework greatly improves students' academic interest. The result could be explained by the fact that teachers' adoption of various instructional techniques appeal to the students' various intelligence address their diverse learning styles and consequently increase their motivation to learning physics.

Table 2 revealed that students taught physics with CAI had a higher mean achievement score than those students taught using the lecture teaching method in the physics achievement test. Data in Table 4.6 shows that the F-ratio is 100.749 with $(1,94)$ degree of freedom. However, since the alpha at 0.05 is greater than the $\mathrm{p}$ value at $0.000 .(p<0.05)$ we reject the null hypothesis and state that there is a significant difference between the mean achievement scores of students taught physics with computer assisted instruction (CAI) and those taught using lecture teaching method as measured by PAT. Moreover, there is a statistically significant difference between adjusted mean of the two Teaching Method used (Adjusted R Squared $=.558$ ). This suggests that students treated with CAI performed better than those in the control groups. The findings of this study revealed 
that the use of computer assisted Instruction method had a significant effect on students" achievement in physics. The students taught using computer assisted instruction method achieved significantly better than those taught using lecture method. This result is in agreement with the result of Dange and Wehb (2006). They found out that computer assisted instruction enhanced students achievement in physics. Tenth grade students in Singapore were treated with computer assisted instruction method and the students in these groups performed significantly better than those without computer assisted concept mapping. This result is also in agreement with Chukwu and Igwebuike (2007), who investigated the effect of integrating concept mapping into computer assisted instruction in chemistry achievement. Their findings revealed that the students in the experimental group who were treated with computer assisted concept mapping achieved significantly better than those in the control group. The trend of higher performance by the treatment (CACM) group could be as a result of self evaluation and remedial activities provided by (CACM) which helped students to master the chemistry concepts without much difficulty than the (LM) group. It could also be as a result of;

i. Excitement over the new approach/handling of personal computers.

ii. Individualized learning by the students and the elimination of teacher bias/strained relationship of teacher and student. Furthermore, the pictorial representations and concept maps provided by the computer which were absent in the LM could be a factor that contributed to the high achievement level of the students.

\section{Conclusions}

Application of computer technology to all aspects of human endeavour coupled with the need to create student-centered classroom to engage learners in their leaning tasks, improve learners' interest and consequently achievement in the school subjects has necessitated the use of computer assisted instruction (CAI) in teaching physics. This study has found out that CAI improved students' achievement and interest in physics than the lecture teaching methods. These results therefore revealed that CAI is a viable alternative to the conventional lecture teaching methods in teaching physics. Moreover, CAI provides powerful tools to support the shift to student-centred learning and is capable of creating a more interactive and engaging learning environment for teachers and learners.

\section{Recommendations}

Based on the findings of this study, the following recommendations are made;

1. More attention should be accorded to computer literacy and operation in the secondary schools and relevant computer assisted instructional packages should be developed for use within the Nigerian school systems.

2. Teachers of physics in Imo State and Nigeria in general should explore the use of the CAI in teaching physics.

3. Further empirical studies should be carried out on why male students performed better than their female counterparts in physics.

4. Curriculum planners and other relevant stakeholders in education such as Nigerian Educational Research and Development Council (NERDC), science teachers association (STAN) should consider review of curriculum for physics for secondary schools with a view of incorporating the use CAI method in our public secondary schools.

\section{References}

[1]. K. Iqbal. Computer Assisted Instruction, School Improvement Research Series, 2009. http://www.nwrel.org/scpd/sirs/5/cu10.html.

[2]. L. W. Ezenwa. Concepts: An overview. In A. E. Kazdin (Ed.), Encyclopedia of Psychology. Oxford University Press, New York 55 Adeyemi, W. A. (2010). Science Teaching in Nigeria. Atoto Publishing Company, Ilorin; 2011, 42-50.

[3]. O. A. Alebiosu, \& O. Y. O. Mudasiru. Effects of Computer Assisted Instruction (CAI) on Secondary School Students' Performance in Biology. The Turkish Online Journal of Educational Technology,2008, 9(1):43-50.

[4]. F. E. Ogunleye. Some Student Personal Variables as Predictors of Mathematics Achievement in Secondary Schools in Central Cross River State, Nigeria. M.Ed. Thesis university of Calabar, Calabar. 2000, Unpublished.

[5]. M. Eyibe. Managing Teachers and the Instruction of Mathematics and Science: Lessons from the SMASSE Experience in Capacity Development. Paper presented at Secondary Education in Africa (SEIA) Follow-up Technical Workshop on Science and Mathematics,2010. Retrieved August 4, 2012 from http://info.worldbank.org/etools/docs/library/245737/day8 2b. PAPER Lessons from SMASSEOradoMaichael.pdf Washington, DC.

[6]. Y. C. Jegede. Effects of Computer Assisted Instruction on Students Achievement in Taiwan; a Metal Analysis. Computer and Education, 2012, 48 (2) 216-233.

[7]. M. Salau. Effect of Concept Mapping in Science - on Science Achievement, Cognitive Skills and Attitude of Students. 2006.Retrieved August 4, 2012 from http://www.hbcse.tifr.res.in/episteme/episteme1/themes/manjularao\%20modified.pdf

[8]. I.O. Adepoju, B. Ivowi, C. Okebukola, N. Oludotun, S. Akpan, \& J. Howden. Classroom Connections: Understanding and using Cooperative Learning. City: Hartcourt Brace and Company,2002, 67-82.

[9]. O. O.Okebukola. Workshop Organisation, Safety and Gender Equality in TVE at Secondary Education Level. 2007, A paper presented at 2008 Serminar/workshop Services of Nigerian Association of Teachers of Technology (NATT). Held at Federal College of Education (Technical). Akoka.

[10]. M. A. Olubusuyi. Recent Innovations in the Training of Teachers/Trainers in Technical and Vocational Education in Asia and the Pacific.2003, Retrieved March 20, 2006., from http://www.unevoc.unesco.org/publication/studiesilepdf. 
[11]. S. Braimoh. A Meta Analysis of the Effectiveness of Computer Assisted Instruction in Science Education. The Journal of Research on Technology in Education,2001, 34(2), 173-188.

[12]. J. Folaranmi. Using a Computerized Concept Mapping Programme to Assess Pre-service Teachers' Thinking about Effective Teaching. Journal of Research in Science Teaching, 2002, 27(10). 66-69.

[13]. J. D. Olaleye. Alternative Instructional Systems and the Development of Problem Solving Skills in Physics. European Journal Of Science Education, 2002, 7(3). 76-84.

[14]. A. Olanrewaju. A Handbook on Understanding Computer Education. College of Technology Press. Yaba, Lagos.2004.

[15]. J. Ajewole. Pre-School Children's Preferences of Different Types of CAI Programmes. Educational Computer Magazine, 2004, $3,38-40$

[16]. M. R. Busari. Female Education in Science, Technology and Mathematics and Sustainable Development in the Millennium. 50 ${ }^{\text {th }}$ Annual Conference proceeding of Science Teachers Association (STAN). 2006, 86-88

[17]. W. Igwebuike. Bloom's Taxonomy of the Cognitive Domain. Educational Psychology. Valdosta GA: Valdosta State University.2006, 5(2) 4.

[18]. B. Odubunmi. Educator Courseware for Statistics and Basic. A PGDCS Thesis. University of Benin. 2001, Unpublished

[19]. A. Ikeobi \& I. S. Ivowi. Introduction to Research Methodology in Education. Fulladu Publishers in Southeast Asia.2005, 44.

[20]. A. D. Schiefele. Influence of School Environmental Variables on Academic Performance as Perceived by Students. M. Ed. thesis. University of Nigeria, Nsukka. 2008, Unpublished.

[21]. J. Hidi. The Principalship Foundations and Functions.. Harper and Row Publishers. New York. $2000,104$.

[22]. K. Meera. Secondary Instructional Methods. Available at: http://www.informaticsffalo.edutechnologies. Retrieved on 1/9/2011. methods. New York: Macmillan.

[23]. A. Patel, A. K. Dupaul, \& A. K. Kinnary. The Effects of Computer Instruction on the Mathematics Performance and Classroom Behaviour of Children with ADHD. Journal of Attention Disorder,2008, 9 (1) 301-312.

[24]. O. Kadhiravan. Instructional Media Technology and Services for Special Learners. Nigerian Journal of Educational Media and Technology.2009, Vol 13:5.

[25]. W. J. Harackiewicz. Effects of Take-home Tests and Study Questions on Retention of Learning in Technology Education. Journal of Technology Education, 2003, 14 (2). 33

[26]. B. Dalwadi. Making Sense of the Future. A Position Paper on the Role of Science, Mathematics and Computer Education, Harps, New York. 2001, 66.

[27]. Y. H. Chukwu. The Effect of Computer Assisted Instruction on Students. Journal of Educational Technology, 2007, 2(4).131-42.

[28]. R. A. Singh. On the Psychometrics of Assessing Science Understanding. In J. Novak, J. Mintzes, and J. Wandersee (Eds.), Assessing Science Understanding: A Human Constructivist View. Academic Press, California. 2008.

[29]. G. S. Dange \& K. Wahb. Effect of Computer-Assisted Instruction Versus Traditional Modes of Instruction on Students Learning of Musculos Skeletal Special Test. Journal of Physical Therapy Education, 2006, 19 (2)22-30. 